\title{
Role of myeloid derived suppressor cells in tuberculosis infection and disease
}

\author{
Nathella Pavan Kumar ${ }^{1,2^{*}}$, Rathinam Sridhar ${ }^{3}$, Vaithilingam V Banurekha², Mohideen S Jawahar ${ }^{2}$, \\ Thomas B Nutman ${ }^{4}$, Subash Babu ${ }^{1,4}$ \\ From 2nd International Science Symposium on HIV and Infectious Diseases (HIV SCIENCE 2014) \\ Chennai, India. 30 January - 1 February 2014
}

\section{Background}

Mycobacterium tuberculosis infects 2 billion people worldwide, $90 \%$ of infected individuals are able to resist overt disease development and manifest only latent infection. Myeloid derived suppressor cells (MDSCs) are a heterogeneous population of early myeloid progenitors, immature granulocytes, macrophages, and dendritic cells at different stages of differentiation. These cells have the capacity to suppress activities of adaptive immune response mediated by $\mathrm{CD} 4^{+}$and $\mathrm{CD}^{+} \mathrm{T}$ cells.

\section{Methods}

The frequency of MDSC(CD45+CD14+HLA dR-), Granulocyte derived MDSC (CD45+CD33+HLA dR CD14 $\mathrm{CD} 11 \mathrm{~b}+)$ and Monocyte derived MDSC(CD45+CD33 + HLA dR CD14+CD11b+) was examined by using flow cytometry in pulmonary tuberculosis $(\mathrm{PTB})(\mathrm{n}=115)$ and compared with extra-pulmonary TB (ETB) $(\mathrm{n}=106)$, latent TB (LTB) $(\mathrm{n}=102)$ and healthy controls $(\mathrm{HC})(\mathrm{n}=73)$

\section{Results}

PTB is characterized by significantly elevated frequencies of MDSC (Geometric mean [GM] of $0.5587 \%$ in PTB and $0.3095 \%$ in EP; $p=0.0005$ ); G-MDSC (GM of $0.1660 \%$ in PTB and $0.3089 \%$ in EP; $p=0.0189$ ) and M-MDSC (GM of $0.1307 \%$ in PTB and $0.0756 \%$ in EP; $p=0.0128$ ) when compared with ETB. On the other hand, there was diminished frequency of MDSC (GM of $0.5587 \%$ in PTB and $1.064 \%$ in LTB; $p=0.0060$ ) (GM of $0.5587 \%$ in PTB and $1.187 \%$ in $\mathrm{HC} ; p<0.0001$ ) and G-MDSC (GM of $0.1660 \%$ in PTB and $0.4131 \%$ in $\mathrm{HC} ; p<0.0001$ ) (GM of $0.1660 \%$ in PTB and

\footnotetext{
* Correspondence: pavanmedtech@gmail.com

'National Institutes of Health international Center for Excellence in Research, Chennai, India

Full list of author information is available at the end of the article
}

$0.3516 \%$ in $\mathrm{HC} ; p<0.0001)$ in PTB group when compared with LTB and $\mathrm{HC}$, respectively.

\section{Conclusions}

The data reveals that MDSC were not only induced during active pulmonary $\mathrm{TB}$ infection but also in latent $\mathrm{TB}$ and healthy controls after recent exposure to $M$. tuberculosis.

\section{Authors' details}

'National Institutes of Health international Center for Excellence in Research, Chennai, India. ${ }^{2}$ National Institute for Research in Tuberculosis, Chennai, India. ${ }^{3}$ Government Stanley Medical Hospital, Chennai, India. ${ }^{4}$ Laboratory of Parasitic Diseases, National Institutes of Allergy and Infectious Diseases, National Institutes of Health, Bethesda, Maryland, USA.

Published: 27 May 2014

doi:10.1186/1471-2334-14-S3-018

Cite this article as: Kumar et al:: Role of myeloid derived suppressor cells in tuberculosis infection and disease. BMC Infectious Diseases 2014 14(Suppl 3):018.

\section{Submit your next manuscript to BioMed Central and take full advantage of: \\ - Convenient online submission \\ - Thorough peer review \\ - No space constraints or color figure charges \\ - Immediate publication on acceptance \\ - Inclusion in PubMed, CAS, Scopus and Google Scholar \\ - Research which is freely available for redistribution \\ Submit your manuscript at www.biomedcentral.com/submit \\ () Biomed Central}

